\title{
Chemical composition and antimicrobial activity of leaves essential oil of Juniperus communis (Cupressaceae) grown in Republic of Macedonia
}

\author{
Floresha Sela ${ }^{1}$, Marija Karapandzova ${ }^{1}$, Gjose Stefkov $^{1}$, Ivana Cvetkovikj ${ }^{1 *}$, \\ Elena Trajkovska-Dokik ${ }^{2}$, Ana Kaftandzieva², Svetlana Kulevanova ${ }^{1}$ \\ 'Institute of Pharmacognosy, Faculty of Pharmacy, University”'Ss. Cyril and Methodius", str. Majka Tereza 47, 1000 \\ Skopje, R. Macedonia \\ ${ }^{2}$ Institute of Microbiology and Parasitology, Faculty of Medicine, University"Ss. Cyril and Methodius", str. 50 Divizija \\ No.6, 1000 Skopje, R. Macedonia
}

Received: June 2013; Accepted: July 2013

\begin{abstract}
Chemical composition and antimicrobial activity of essential oils isolated from leaves of three different samples of wild growing Juniperus communis L. (Cupressaceae) from R. Macedonia was investigated. Essential oil yield ranged from 7.3 to $9.0 \mathrm{ml} / \mathrm{kg}$. Performing GC/ FID/MS analysis, ninety components were identified, representing 86.07-93.31\% of the oil. The major components of the leaves essential oil (LEO) were $\alpha$-pinene (21.37-28.68\%) and sabinene (2.29-16.27\%), followed by limonene, terpinen-4-ol, $\beta$-elemene, trans-(E)-caryophyllene, germacrene $\mathrm{D}$ and $\delta$-cadinene. Antimicrobial screening of the LEO was made by disc diffusion and broth dilution method against 16 bacterial isolates of Gram positive and Gram negative bacteria and one strain of Candida albicans. Two bacteria, Staphylococcus aureus and Streptococcus pyogenes were sensitive to antimicrobial activity of LEO (MIC $=125 \mu 1 / \mathrm{ml}$ ). Additionally, LEO showed moderate antimicrobial activity against Streptococcus agalactiae, Haemophilus influnzae, Corynebacterium spp. and Campylobacter jejuni (MIC > $500 \mu 1 / \mathrm{ml}$ ). Candida albicans, Staphylococcus epidermidis, Acinetobacter spp., Salmonella enteritidis, Shigella flexneri, Klebsiella pneumonia, Pseudomonas aeruginosa and Proteus mirabilis were completely resistant to the antimicrobial effects of this.
\end{abstract}

Keywords: Juniperus communis, leaves essential oil, oil composition, GC/FID/MS analysis, antimicrobial activity

\section{Introduction}

The common juniper, Juniperus communis $\mathrm{L}$. (Cupressaceae), is an evergreen shrub or small coniferous tree, wide spread through the cool temperate Northern Hemisphere. The above-ground parts, especially leaves and berries of juniper are rich in essential oil that has characteristic aromatic flavour and bitter taste. Due to its diuretic and gastrointestinal properties, common juniper is used as me-

\footnotetext{
*email:ivanacvetkovikj@gmail.com, ivanacvetkovic@yahoo.com
}

dicinal plant for centuries. Juniper oil is used in the pharmaceutical, food and cosmetic industries, as well as for the production of perfumes. Certain beverages (gin) are made with distillation from fermented juniper berries.

According to the literature data, juniper essential oil can be obtained from berries, leaves, wood and seeds by hydrodistillation (Orav et al., 2010a; Chatzopoulou and Katsiotis, 1993; Kumar et al., 2007). The average oil yield varies from 0.5 to $2.5 \%$ (for berries) and from 0.2 to $1.0 \%$ (for needles) (Orav et al., 2010a). Dissimilarities in the oil's yield and the chemical composition can vary from the geo- 
Table 1. Plant samples of Juniperus communis from R. Macedonia

\begin{tabular}{clccc}
\hline \hline \multicolumn{1}{c}{ Species } & \multicolumn{1}{c}{ Locality } & Altitude & $\begin{array}{c}\text { Herbarium voucher } \\
\text { specimen }\end{array}$ & $\begin{array}{c}\text { Sample } \\
\text { abbreviation }\end{array}$ \\
\hline Juniperus communis L. & Jelak (Shara Mtn.) & $1800 \mathrm{~m}$ & $\mathrm{~N}^{\circ} \mathrm{JC}-16 / 10$ & $\mathrm{JcS} / 10$ \\
Juniperus communis L. & Velestovo (Galichica Mtn.) & $1000 \mathrm{~m}$ & $\mathrm{~N}^{\circ} \mathrm{JC}-5.1 . / 11$ & $\mathrm{JcG} / 11$ \\
Juniperus communis L. & Kicevo (Bistra Mtn) & $600 \mathrm{~m}$ & $\mathrm{~N}^{\circ} \mathrm{JC}-1 / 11$ & $\mathrm{JcB} / 11$ \\
\hline
\end{tabular}

graphical location, age and degree of plant ripeness, harvesting methods, distillation techniques and other factors.

There are many publications reporting the essential oil composition of juniper berries and leaves (Orav et al., 2010a; Chatzopoulou and Katsiotis, 1993; Kumar et al., 2007, Ottavioli et al., 2009; Filipowicz et al., 2009; Shahmir et al., 2003; Orav et al., 2010b). Considerable variations in the oil composition were observed depending on the plant origin but often the essential oils were rich in $\alpha$-pinene, sabinene and myrcene, followed by trans-(E)caryophyllene, muurolene, germacrene D and B and humulene (Orav et al., 2010a). As major oxygen containing terpene were terpinen-4-ol (Chatzopoulou and Katsiotis, 1993), rarely citronellol (Koukos and Papadopoulou, 1997) and terpenyl acetate (Angioni et al., 2003).

In vitro antimicrobial (antibacterial and antifungal) activity of the berries essential oil was studied and the results showed strong to moderate antimicrobial activity (Filipowitz et al. 2003; Stassi et al. 1995). Other results from the antimicrobial assessment of the leaves essential oil (LEO) demonstrate no or weak antimicrobial activity against various tested microbial strains (Asili et al., 2008; Angioni et al., 2003).

Common juniper, Juniperus communis, is widely spread shrub throughout the territory of Republic of Macedonia (Micevski, 1998). The berries of this plant are extensively utilized in production of blended teas and other herbal medicinal products, in food industry, as a spice, in production of alcoholic beverages, etc. For years, the juniper berries and the juniper essential oil are exported from R. Macedonia. On the other hand the juniper leaves are used in folk medicine for various purposes. Up to date there is no information of the composition and antimicrobial activity of the leaves' essential oil from Macedonian juniper. Therefore the aim of the present study was to investigate the chemical composition and the antimicrobial activity of the leaves essential oil of Juniperus communis grown wild in R. Macedonia.

\section{Material and methods}

\section{Plant materials}

The terminal twigs of Juniperus communis were collected from tree different localities in R. Macedonia in late autumn 2010 and 2011. Plant identity was verified as Juni- perus communis L. and herbarium voucher specimen were deposited at the Department of Pharmaceutical Botany, Institute of Pharmacognosy, Faculty of Pharmacy, Skopje, R. Macedonia (Table 1).

The plant material was dried at room temperature. Just before essential oil isolation, the juniper leaves were separated and minced properly.

\section{Chemicals}

Dimethylsulfoxide was purchased from Sigma-Aldrich (Steinheim, Germany), sodium chloride and anhydrous sodium sulfate from Merck (Darmstadt, Germany) and from Kemica (Zagreb, Croatia), respectively, while xylene was purchased from Alkaloid (Skopje, R. Macedonia).

\section{Essential oil isolation}

The essential oils were obtained from dried plant material through steam distillation using all glass Clevenger-type apparatus. For that purpose, $20 \mathrm{~g}$ of minced plant material was distilled for 4 hours. After isolation, anhydrous sodium sulfate was added to remove residual water from the oil. The essential oil yield was calculated on dried plant material and was expressed in $\mathrm{ml} / \mathrm{kg}$. For $\mathrm{GC} /$ FID/MS analysis, the essential oil was dissolved in xylene to obtain $1 \mu \mathrm{l} / \mathrm{ml}$ oil solution.

\section{Gas chromatography $(G C)$ and gas chromatography/mass spectrometry $(G C / M S)$}

Essential oil samples were analyzed on Agilent 7890A Gas Chromatography system equipped with FID detector and Agilent 5975C Mass Quadrupole detector as well as capillary flow technology which enables simultaneous analysis of the samples on both detectors. For that purpose, HP-5ms capillary column $(30 \mathrm{~m} \times 0.25 \mathrm{~mm}$, film thickness $0.25 \mu \mathrm{m}$ ) was used. Operating conditions were as follows: oven temperature at $60{ }^{\circ} \mathrm{C}(5 \mathrm{~min}), 1{ }^{\circ} \mathrm{C} / \mathrm{min}$ to 80 ${ }^{\circ} \mathrm{C}(2 \mathrm{~min})$ and $5{ }^{\circ} \mathrm{C} / \mathrm{min}$ to $280{ }^{\circ} \mathrm{C}(5 \mathrm{~min})$; helium as carrier gas at a flow rate of $1 \mathrm{ml} / \mathrm{min}$; injector temperature 260 ${ }^{\circ} \mathrm{C}$ and that of the FID $270{ }^{\circ} \mathrm{C}$. $1 \mu \mathrm{l}$ of each sample was injected at split ratio $1: 1$. The mass spectrometry conditions were: ionization voltage $70 \mathrm{eV}$, ion source temperature 230 
${ }^{\circ} \mathrm{C}$, transfer line temperature $280{ }^{\circ} \mathrm{C}$ and mass range from 50 - $500 \mathrm{Da}$. The MS was operated in scan mode.

\section{Identification of the components}

Identification of the components present in essential oils was made by comparing mass spectra of components in essential oils with those from Nist, Wiley and Adams mass spectra libraries, by AMDIS (Automated Mass Spectral Deconvolution and Identification System) and by comparing literature and estimated Kovat's (retention) indices that were determined using mixture of homologous series of normal alkanes from $\mathrm{C}_{9}$ to $\mathrm{C}_{25}$ in hexane, under the same above mentioned conditions.

The percentage ratio of essential oils components was computed by the normalization method of the GC/FID peak areas without any correction factors.

\section{Antimicrobial activity: Microbial strains and cultures}

16 bacterial isolates representing both Gram positive and Gram negative bacteria and one strain of Candida albicans were used for antimicrobial screening. Five isolates were standard strains (Staphylococcus aureus ATCC 29213, Escherichia coli 25927, Klebsiella pneumoniae ATCC 700603, Pseudomonas aeruginosa ATCC 27853 and Candida albicans ATCC 10231). The remaining 12 bacterial strains (Staphylococcus epidermidis, Enterococcus, Streptococcus pyogenes, Streptococcus agalactiae, Streptococcus pneumoniae, Haemophilus influenzae, Proteus mirabilis, Salmonella enteritidis, Corynebacterium spp., Salmonella enteritidis, Shigella flexneri, Campylobacter jejuni and Acinetobacter spp.) were clinical isolates provided from the Institute of Microbiology and Parasitology, Faculty of Medicine, Skopje, R. Macedonia.

A nutrient (Mueller Hinton) agar (Merck, Darmstadt, Germany), blood agar (Oxoid, Basingstoke, UK) and Sabouraud agar (bioMerieux, Durham, NC) were used for growing of the microbes.

\section{Disc diffusion method}

Disc diffusion method was used for screening the antimicrobial activity of all essential oils in order to determine the growth inhibition zones of studied microorganisms that occur around certain essential oil. In this regard, microorganisms were suspended in sterile broth with turbidity corresponding to 0.5 and $1 \mathrm{Mc}$ Farland (approximate by $10^{7}-$ $10^{8} \mathrm{CFU} / \mathrm{ml}$ ) for all bacteria and for Candida albicans, respectively. The microbial suspensions were streaked over the surface of the agar media using a sterile cotton swabs to ensure uniform inoculation. After inoculation of microorganisms, discs of $6 \mathrm{~mm}$ in diameter were made at wellspaced intervals. They were filled with $85 \mu \mathrm{l}$ of $50 \%$ solutions of essential oils in dimethylsulfoxide (DMSO, Sigma-Aldrich, Germany) and one disc was filled only with
DMSO as a control. The plates were incubated at $37{ }^{\circ} \mathrm{C}$, aerobically for 24 hours. The growth inhibition zones were measured after incubation of the isolates under their optimal growth conditions and were ranged between $6 \mathrm{~mm}$ and $30 \mathrm{~mm}$ in diameter. The antimicrobial activity was determined according to the diameters of the inhibition zones (0-14 mm resistant - $\mathrm{R}, 14-19 \mathrm{~mm}$ moderate susceptible $\mathrm{M}$ and 19-30 susceptible - $\mathrm{S}$ microorganisms).

\section{Broth dilution method}

This method was used in order to determine minimal inhibitory concentration (MIC) of the particular essential oil prepared as 50\% solution in DMSO). For that purposes, $25 \mu \mathrm{l}$ of those essential oils were diluted in equal quantities of $0.9 \%$ sodium chloride solution, to make them with the concentration of $25 \%$. This concentration was decreased five times, subsequently, by adding $25 \mu \mathrm{l}$ of each bacterial or fungal suspension, thus the final concentrations were: $12.5 \%, 6.2 \%, 3.1 \%, 1.5 \%$ and $0.7 \%$ or $125 \mu \mathrm{l} / \mathrm{ml}, 62 \mu \mathrm{l} / \mathrm{ml}$, $31 \mu \mathrm{l} / \mathrm{ml}, 15 \mu \mathrm{l} / \mathrm{ml}$ and $7 \mu \mathrm{l} / \mathrm{ml}$, respectively. $15 \mu \mathrm{l}$ of each bacterial or fungal suspensions with these particular concentrations were inoculated on solid media (Miller-Hinton agar, blood agar, Sabouraud agar), depending on the type of microorganism. The growth of any microorganism was evaluated after its incubation under the optimal growth conditions. The lowest concentration of essential oil which was able to inhibit the growth of the particular microorganism was considered as its minimal inhibitory concentration (MIC).

\section{Results and discussion}

The yields of the leaves essential oil were: $7.3,7.3$ and $9.0 \mathrm{ml} / \mathrm{kg}$ for $\mathrm{JcS} / 10, \mathrm{JcB} / 11$ and $\mathrm{JcG} / 11$ respectively. Percentage presence with Kovat's retention indices of ninety identified components representing 86.07-93.31\% of the oil are presented in Table 2. Data analysis of the chemical composition revealed four main classes of components: monoterpene hydrocarbons $(\mathrm{MH})$, oxygen-containing monoterpenes (OM), sesquiterpene hydrocarbons (SH) and oxygen-containing sesquiterpenes (OS). Diterpenes (D) were present in small amounts as well as some non-terpene components (NT). Monoterpene hydrocarbons were the most abundant fraction in all investigated oils $(39.97 \%, 52.32 \%$ and $53.39 \%$, for the samples from Shara Mtn., Galicica Mtn. and Bistra Mtn., respectively), followed by SH $(28.64 \%, 20.66 \%$ and $12.27 \%$, respectively) (Table 2). Oxygen-containing monoterpenes were present in much smaller amounts $3.89 \%$ in samples from Shara Mtn., 6.69\% in samples from Galicica Mtn. and 12.16\% in samples from Bistra Mtn.) as well as the oxygen-containing sesquiterpenes $(13.57 \%, 11.53 \%$ and $5.98 \%$, respectively). The ratios between monoterpenes (M) and sesquiterpenes (S) were 1:1, 2:1 and 3:1 for LEO from Shara Mtn., Galicica Mtn. and Bistra Mtn., respectively (Fig. 1). 


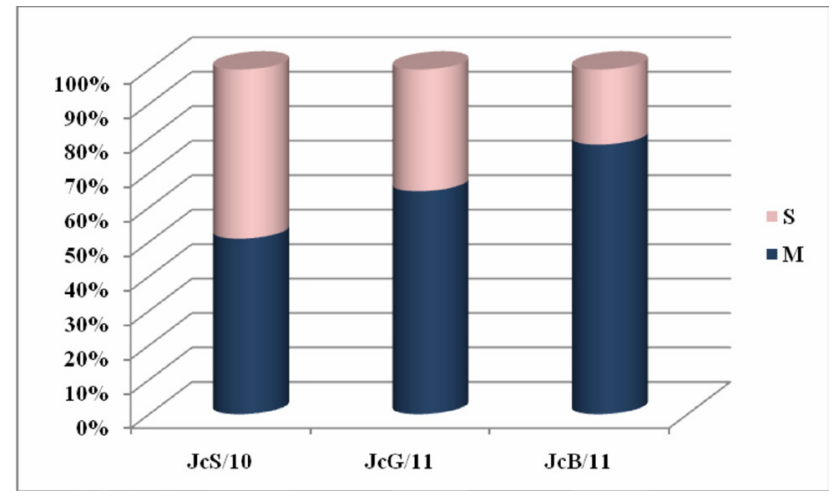

Fig. 1. The monoterpenes $(\mathrm{M}) /$ sesquiterpenes $(\mathrm{S})$ ratio of leaves essential oil from Macedonian juniper

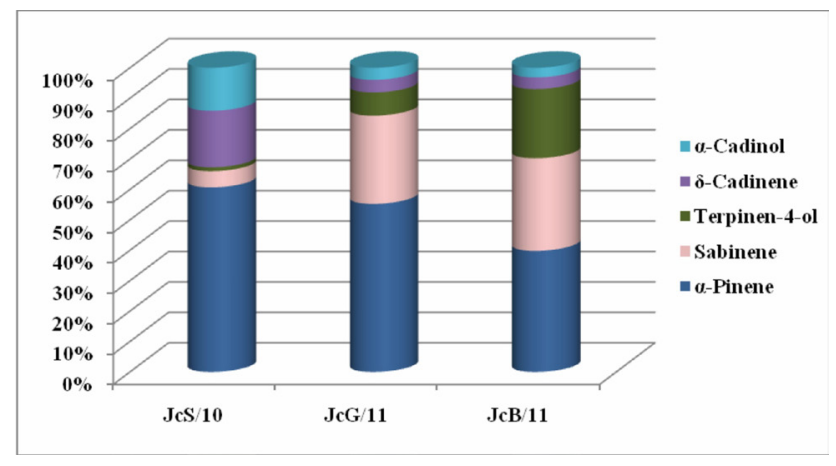

Fig. 2. Predominant components in the leaves essential oil from wild growing $J$. communis in R. Macedonia

GC/FID/MS analysis of the juniper leaves essential oil showed presence of two main components in the samples from Galicica Mtn. and Bistra Mtn.: $\alpha$-pinene (28.68\% and $21.27 \%$, respectively) and sabinene (15.5\% and $16.27 \%$, respectively). Additionally, limonene was identified with $2.82 \%$ and $6.95 \%$, respectively, while terpinene-4-ol was the most abundant oxygen-containing monoterpenes (3.98\% and $12.16 \%$, respectively). Concerning the sesquiterpene fraction, $\beta$-elemene, trans-(E)-caryophyllene, $\alpha$-humulene, germacrene $\mathrm{D}, \delta$-cadinene and $\alpha$-cadinol were present in amounts between 1.37 and 3.45\%. Likewise LEO from Shara Mtn. contained $\alpha$-pinene (26.05\%) as predominant component, followed by smaller amounts of $\delta$-3-carene $(3.15 \%), \beta$-phellandrene $(4.37 \%)$ and sabinene $(2.29 \%)$. Terpinene-4-ol was present with $0.55 \%$. The sesquiterpene components ( $\beta$-elemene, $\delta$-cadinene and $\alpha$ cadinol) were present in amounts up to $7.98 \%$. Evaluation of the occurrence of the main components that characterized the leaves essential oil of Macedonian juniper (Fig.2), showed that sabinene was found in Bistra Mtn. and Galicica Mtn., terpinen-4-ol only in Bistra Mtn., while the sesquiterpenes, $\delta$-cadinene and $\alpha$-cadinol were characteristic for the LEO from Shara Mtn.
Similarity in the composition of the leaves essential oil was found with the Greek $J$. communis where $\alpha$-pinene $(41.25 \%)$ and sabinene $(17.4 \%)$ have been predominant constituents followed by smaller amounts of limonene $(4.2 \%)$, terpinen-4-ol $(2.7 \%), \beta$-myrcene $(2.6 \%)$ and $\beta$-pinene (2.0\%) (Chatzopoulou et al., 1993). Further, the Estonian $J$. communis LEO has been also rich in $\alpha$-pinene (33.3-45.6\%) and sabinene (0.2-15.4\%) while limonene, trans-(E)-caryophyllene, $\alpha$-humulene and germacrene D were present in smaller amounts (Orav et al., 2010a, 2010b). Raal et al. (2010) reported similar composition for the essential oil obtained from branches of $J$. communis from Estonia comparing to the leaves essential oil where $\alpha$-pinene (40.4-62\%) and limonene (4.2-10\%) were dominant components, followed by $\alpha$-cadinol, $\delta$-cadinene, $\gamma$ muurolene and germacrene. LEO from $J$. communis from Lithuania was rich in $\alpha$-pinene (38.5-59.9\%), accompanied by $\beta$-phellandrene (4.1-11.4\%) or $\alpha$-cadinol (one sample of tested essential oil contained 8.7\%) (Butkine et al., 2005). Butkine et al. (2005) have identified 143 components in the juniper LEO which were divided in two groups according to the monoterpenes/sesquiterpenes ratio: $\mathrm{M}: \mathrm{S}=5: 1$ and $\mathrm{M}: \mathrm{S}=2: 1$. Filipowicz et al. (2009) have reported that populations of $J$. communis from Northern Poland have essential oils with different $\alpha$-pinene/sabinene ratio. Iranian authors found that juniper leaves essential oil was rich in sabinene $(40.7 \%)$, than $\alpha$-pinene $(12.5 \%)$ and terpinen-4-ol $(12.3 \%)$ (Shahmir et al., 2003). Asili et al. (2008), confirmed $\alpha$-pinene as predominant component in the Iranian $J$. communis subsp. hemisphaerica LEO, while Ottavioli et al. (2009) for French J. communis subsp. alpina reported limonene (9.2-53.9\%), $\beta$-phellandrene (3.7-25.2\%), $\alpha$-pinene (1.4-33.7\%) and sabinene (0.1-33.6\%) as major constituents. The LEO from Indian J. communis contained predominantly sabinene $(22.8 \%), \beta$-pinene $(10.7 \%)$, transsabinene hydrate $(6.0 \%)$ and $\gamma$-cadinene $(10.6 \%)$ (Kumar et al., 2007).

\section{Antimicrobial activity}

Antimicrobial screening of the essential oils was made by disc diffusion and broth dilution method against 16 bacterial isolates of Gram positive and Gram negative bacteria and one strain of Candida albicans (Table 3). The highest MIC $(125 \mu \mathrm{l} / \mathrm{ml})$ of LEOs were towards Staphylococcus aureus and Streptococcus pyogenes, and moderate antimicrobial activity against Streptococcus agalactiae, Haemophillus influnzae, Corynebacterium spp. and Campylobacter jejuni (MIC > $500 \mu \mathrm{l} / \mathrm{ml})$. Candida albicans, Staphylococcus epidermidis, Acinetobacter spp., Salmonella enteritidis, Shigella flexneri, Klebsiella pneumonia, Pseudomonas aeruginosa and Proteus mirabilis were completely resistant to the antimicrobial activity of juniper oil.

Antimicrobial activity of juniper essential oils was previously investigated so the available literature pointed out no activity to some antimicrobial effects against vari- 
Table 2. The chemical composition of the leaves essential oil (LEO) of Juniperus communis from R. Macedonia

\begin{tabular}{|c|c|c|c|c|c|c|}
\hline No. & Components & KIL & KIE & $\mathrm{JcS} / 10$ & $\mathrm{JcG} / 11$ & $\mathrm{JcB} / 11$ \\
\hline 1 & Tricyclene & 921 & 930.5 & - & 0.04 & - \\
\hline 2 & $\alpha$-Thujene & 924 & 933.3 & - & 0.79 & 2.43 \\
\hline 3 & $\alpha$-Pinene & 932 & 937.5 & 26.05 & 28.68 & 21.27 \\
\hline 4 & Camphene & 946 & 946.3 & 0.18 & 0.91 & - \\
\hline 5 & n-Heptanol & 959 & 946.5 & - & - & 5.69 \\
\hline 6 & Sabinene & 969 & 962.6 & 2.29 & 15.05 & 16.27 \\
\hline 7 & $\beta$-Pinene & 974 & 964.2 & 2.28 & $\operatorname{tr}$ & - \\
\hline 8 & $\beta$-Myrcene & 988 & 975.7 & 0.55 & 1.69 & 2.12 \\
\hline 9 & $\delta$-2-Carene & 1001 & 982.1 & 0.16 & 0.17 & - \\
\hline 10 & $\alpha$-Phellandrene & 1002 & 995.2 & 0.38 & - & - \\
\hline 11 & $\delta$-3-Carene & 1008 & 989.7 & 3.15 & 0.22 & - \\
\hline 12 & $\alpha$-Terpinene & 1014 & 995.3 & - & 0.12 & - \\
\hline 13 & $p$-Cymene & 1020 & 1002 & 0.56 & 1.43 & $\operatorname{tr}$ \\
\hline 14 & $o$-Cymene & 1022 & 1003 & - & - & 4.35 \\
\hline 15 & Limonene & 1024 & 1005 & - & 2.82 & 6.95 \\
\hline 16 & $\beta$-Phellandrene & 1025 & 1016 & 4.37 & - & - \\
\hline 17 & $\gamma$-Terpinene & 1054 & 1033 & - & 0.23 & - \\
\hline 18 & Terpinolene & 1086 & 1062 & - & 0.21 & - \\
\hline 19 & Isopentyl 2-methylbutanoate & 1100 & 1083 & - & 0.1 & - \\
\hline 20 & $\alpha$-Campholenal & 1122 & 1102 & - & 0.16 & - \\
\hline 21 & trans-Pinocarveol & 1135 & 1118 & 0.47 & 0.18 & - \\
\hline 22 & trans-Verbenol & 1140 & 1128 & 1.16 & 0.37 & - \\
\hline 23 & 3-methyl-2-butenyl 3-methyl-Butanoate & 1147 & 1138 & - & 0.02 & - \\
\hline 24 & Borneol & 1165 & 1150 & 0.28 & 0.09 & - \\
\hline 25 & Terpinen-4-ol & 1174 & 1161 & 0.55 & 3.96 & 12.16 \\
\hline 26 & p-Cymene-8-ol & 1179 & 1170 & - & 0.24 & - \\
\hline 27 & $\alpha$-Terpineol & 1186 & 1174 & 0.37 & 0.33 & - \\
\hline 28 & Myrtenol & 1194 & 1178 & - & 0.29 & - \\
\hline 29 & Verbenone & 1204 & 1187 & $\operatorname{tr}$ & 0.27 & - \\
\hline 30 & trans-Carveol & 1215 & 1195 & - & 0.08 & - \\
\hline 31 & $\beta$-Citronellol & 1223 & 1205 & - & 0.1 & - \\
\hline 32 & Thymol methyl ether & 1232 & 1210 & - & 0.05 & - \\
\hline 33 & cis-Myrtanol & 1249 & 1248 & 0.15 & - & - \\
\hline 34 & Bornyl acetate & 1284 & 1260 & 0.78 & 0.42 & - \\
\hline 35 & trans-Sabinyl acetate & 1289 & 1280 & 0.13 & - & - \\
\hline 36 & Terpinen-7-al & 1290 & 1268 & - & 0.03 & - \\
\hline 37 & $\delta$-Elemene & 1335 & 1305 & 0.14 & 0.07 & - \\
\hline 38 & $\alpha$-Cubebene & 1345 & 1319 & 0.12 & 0.09 & - \\
\hline 39 & $\alpha$-Ylangene & 1373 & 1341 & - & 0.04 & - \\
\hline 40 & $\alpha$-Copaene & 1374 & 1345 & - & 0.62 & 0.67 \\
\hline 41 & $\beta$-Bourbonene & 1387 & 1354 & - & 0.32 & - \\
\hline 42 & $\beta$-Elemene & 1389 & 1362 & 4.17 & 2.62 & 1.37 \\
\hline 43 & Sibirene & 1400 & 1384 & 2.31 & 0.39 & 0.31 \\
\hline 44 & 2-epi-Funebrene & 1411 & 1394 & 0.08 & - & - \\
\hline
\end{tabular}




\begin{tabular}{|c|c|c|c|c|c|c|}
\hline No. & Components & KIL & KIE & $\mathrm{JcS} / 10$ & $\mathrm{JcG} / 11$ & $\mathrm{JcB} / 11$ \\
\hline 45 & trans-(E)-Caryophyllene & 1417 & 1387 & 0.81 & 3.45 & 1.52 \\
\hline 46 & $\beta$-Copaene & 1430 & 1396 & 0.13 & 0.2 & - \\
\hline 47 & $\gamma$-Elemene & 1434 & 1400 & 2.95 & 0.58 & 0.67 \\
\hline 48 & Sesquterpene $e^{* 1}$ & / & 1405 & - & 0.04 & - \\
\hline 49 & Sesquterpene ${ }^{* 2}$ & / & 1411 & - & 0.11 & - \\
\hline 50 & trans-Muurola-3,5-diene & 1451 & 1418 & 0.1 & $\operatorname{tr}$ & - \\
\hline 51 & $\alpha$-Humulene & 1452 & 1421 & 1.07 & 2.89 & 1.37 \\
\hline 52 & cis-Muurola-4(14),5-diene & 1465 & 1431 & 0.26 & 0.21 & - \\
\hline 53 & Germacrene D & 1484 & 1450 & 2.45 & 3.23 & 1.43 \\
\hline 54 & $\beta$-Selinene & 1489 & 1455 & 0.1 & 0.53 & 0.64 \\
\hline 55 & $\alpha$-Selinene & 1498 & 1463 & 1.07 & 0.88 & 0.7 \\
\hline 56 & $\alpha$-Muurolene & 1500 & 1468 & 1.32 & 0.61 & 0.45 \\
\hline 57 & $\delta$-Amorphene & 1511 & 1487 & 0.21 & - & - \\
\hline 58 & $\gamma$-Cadinene & 1513 & 1481 & 2.26 & 0.9 & 0.6 \\
\hline 59 & $\delta$-Cadinene & 1522 & 1490 & 7.98 & 2.15 & 2.05 \\
\hline 60 & trans-Cadina-1.4-diene & 1533 & 1498 & 0.31 & 0.1 & - \\
\hline 61 & $\alpha$-Cadinene & 1537 & 1517 & 0.5 & - & - \\
\hline 62 & $\alpha$-Calacorene & 1544 & 1510 & 0.2 & 0.22 & - \\
\hline 63 & Elemol & 1548 & 1516 & 0.31 & 0.16 & - \\
\hline 64 & Germacrene B & 1559 & 1525 & - & 0.41 & 0.49 \\
\hline 65 & Nerolidol E & 1561 & 1528 & - & 0.5 & - \\
\hline 66 & Germacrene D-4-ol & 1574 & 1544 & - & $\operatorname{tr}$ & - \\
\hline 67 & Spathulenol & 1577 & 1546 & - & 1.67 & 1.06 \\
\hline 68 & Caryophyllene oxide & 1582 & 1552 & - & 1.73 & 0.78 \\
\hline 69 & Viridiflorol & 1592 & 1563 & - & 0.29 & - \\
\hline 70 & Humulene epoxide II & 1608 & 1578 & 0.77 & 1.17 & 0.71 \\
\hline 71 & 1,10-di-epi 1-epi-Cubenol & 1618 & 1582 & $\operatorname{tr}$ & $\operatorname{tr}$ & - \\
\hline 72 & 1-epi-Cubenol & 1627 & 1595 & 2.31 & 0.51 & 0.39 \\
\hline 73 & $\tau$-Murolol (epi- $\alpha$-Muurolol) & 1640 & 1609 & 4.13 & 1.32 & 1.07 \\
\hline 74 & $\alpha$-Muurolol & 1644 & 1613 & - & 0.44 & 0.3 \\
\hline 75 & $\alpha$-Cadinol & 1652 & 1622 & 6.05 & 2.04 & 1.67 \\
\hline 76 & Cadalene & 1675 & 1624 & - & $\operatorname{tr}$ & - \\
\hline 77 & Sesquterpene ${ }^{* 3}$ & / & 1654 & - & 0.34 & - \\
\hline 78 & Shyobunol & 1685 & 1659 & - & 0.31 & - \\
\hline 79 & 8-Cedren-13-ol & 1688 & 1676 & - & 0.26 & - \\
\hline 80 & Sesquterpene ${ }^{* 4}$ & / & 1690 & - & 0.21 & - \\
\hline 81 & Oplopanone & 1739 & 1705 & - & 0.23 & - \\
\hline 82 & Sesquterpene ${ }^{* 5}$ & / & 1778 & - & 0.23 & - \\
\hline 83 & (Z)-Lanceol & 1760 & 1790 & - & 0.12 & - \\
\hline 84 & Pimaradiene & 1948 & 1934 & - & 0.06 & - \\
\hline 85 & Manool oxide & 1987 & 1962 & - & 0.27 & - \\
\hline 86 & Abietatriene & 2055 & 2025 & - & 0.62 & 0.32 \\
\hline 87 & Abietadiene & 2087 & 2052 & - & 0.12 & - \\
\hline 88 & dehydro-Abietal & 2274 & 2238 & - & 0.03 & - \\
\hline 89 & Abietal & 2313 & 2278 & - & 0.04 & - \\
\hline
\end{tabular}




\begin{tabular}{clccccc}
\hline \hline No. & Components & KIL & KIE & JcS/10 & JcG/11 & JcB/11 \\
\hline 90 & Octacosane & 2800 & 2822 & - & 0.93 & - \\
& & & & & & \\
& Non-terpene components (NT) & & & - & 0.97 & 5.69 \\
& Monoterpene hydrocarbons (MH) & & 39.97 & 52.32 & 53.39 \\
& Oxygen-containing monoterpenes (OM) & & 3.89 & 6.69 & 12.16 \\
& Sesquiterpene hydrocarbons (SH) & & 28.64 & 20.66 & 12.27 \\
& Oxygen-containing sesquiterpenes (OS) & & 13.57 & 11.53 & 5.98 \\
& Diterpenes (D) & & - & 1.14 & 0.32 \\
& Total (\%) & & 86.07 & 93.31 & 89.81 \\
\hline
\end{tabular}

KIL - Kovat's (retention) index - literature data (Adams, 2007); KIE - Kovat's (retention) index experimentally determined (AMDIS); (-) - not found, $\operatorname{tr}$ - traces $<0.02,{ }^{{ }^{1}, 2,3,4,5}$ - tentative identification.

Table 3. Antimicrobial activity of the leaves essential oil of Juniperus communis

\begin{tabular}{|c|c|c|c|c|c|}
\hline No. & Microorganism & & $\mathrm{JcS} / 10$ & $\mathrm{JcG} / 11$ & $\mathrm{JcB} / 11$ \\
\hline \multirow{2}{*}{1} & \multirow{2}{*}{ Streptococcus pneumoniae } & $\mathrm{DD}$ & $\overline{\mathrm{R}}$ & $\overline{\mathrm{R}}$ & $\overline{\mathrm{R}}$ \\
\hline & & MIC & n.m. & n.m. & n.m. \\
\hline \multirow{2}{*}{2} & \multirow{2}{*}{ Staphylococcus aureus } & $\mathrm{DD}$ & $\mathrm{S}$ & $\mathrm{S}$ & $\mathrm{S}$ \\
\hline & & MIC & 125 & 125 & 125 \\
\hline \multirow{2}{*}{3} & \multirow{2}{*}{ Staphylococcus epidermidis } & $\mathrm{DD}$ & $\mathrm{R}$ & $\mathrm{R}$ & $\mathrm{R}$ \\
\hline & & MIC & n.m. & n.m. & n.m. \\
\hline \multirow{2}{*}{4} & \multirow{2}{*}{ Streptococcus agalactiae } & $\mathrm{DD}$ & $\mathrm{M}$ & $\mathrm{R}$ & $\mathrm{R}$ \\
\hline & & MIC & $>500$ & n.m. & n.m. \\
\hline \multirow{2}{*}{5} & \multirow{2}{*}{ Streptococcus pyogenes } & $\mathrm{DD}$ & $\mathrm{S}$ & M & M \\
\hline & & MIC & 125 & $>500$ & $>500$ \\
\hline \multirow{2}{*}{6} & \multirow{2}{*}{ Enterococcus } & $\mathrm{DD}$ & $\mathrm{R}$ & $\mathrm{R}$ & $\mathrm{R}$ \\
\hline & & MIC & n.m. & n.m. & n.m. \\
\hline \multirow{2}{*}{7} & \multirow{2}{*}{ Corynebacterium spp. } & $\mathrm{DD}$ & $\mathrm{M}$ & $\mathrm{R}$ & $\mathrm{R}$ \\
\hline & & MIC & $>500$ & n.m. & n.m. \\
\hline \multirow{2}{*}{8} & \multirow{2}{*}{ Haemophilus influenzae } & $\mathrm{DD}$ & $\mathrm{M}$ & $\mathrm{M}$ & $\mathrm{M}$ \\
\hline & & MIC & $>500$ & $>500$ & $>500$ \\
\hline \multirow{2}{*}{9} & \multirow{2}{*}{ Acinetobacter spp. } & $\mathrm{DD}$ & $\mathrm{R}$ & $\mathrm{R}$ & $\mathrm{R}$ \\
\hline & & MIC & n.m. & n.m. & n.m. \\
\hline \multirow{2}{*}{10} & \multirow{2}{*}{ Escherichia coli } & $\mathrm{DD}$ & $\mathrm{R}$ & $\mathrm{R}$ & $\mathrm{R}$ \\
\hline & & MIC & n.m. & n.m. & n.m. \\
\hline \multirow{2}{*}{11} & \multirow{2}{*}{ Salmonella enteritidis } & DD & $\mathrm{R}$ & $\mathrm{R}$ & $\mathrm{R}$ \\
\hline & & MIC & n.m. & n.m. & n.m. \\
\hline \multirow{2}{*}{12} & \multirow{2}{*}{ Shigella flexneri } & $\mathrm{DD}$ & $\mathrm{R}$ & $\mathrm{R}$ & $\mathrm{R}$ \\
\hline & & MIC & n.m. & n.m. & n.m. \\
\hline \multirow{2}{*}{13} & \multirow{2}{*}{ Campylobacter jejuni } & $\mathrm{DD}$ & $\mathrm{M}$ & $\mathrm{M}$ & $\mathrm{M}$ \\
\hline & & MIC & $>500$ & $>500$ & $>500$ \\
\hline \multirow{2}{*}{14} & \multirow{2}{*}{ Klebsiella pneumoniae } & $\mathrm{DD}$ & $\mathrm{R}$ & $\mathrm{R}$ & $\mathrm{R}$ \\
\hline & & MIC & n.m. & n.m. & n.m. \\
\hline \multirow{2}{*}{15} & Pseudomonas aеruoinos & $\mathrm{DD}$ & $\mathrm{R}$ & $\mathrm{R}$ & $\mathrm{R}$ \\
\hline & Pseudomonas aeruginosa & MIC & n.m. & n.m. & n.m. \\
\hline 16 & Protous mirahilis & $\mathrm{DD}$ & $\mathrm{R}$ & $\mathrm{R}$ & $\mathrm{R}$ \\
\hline 10 & Proteus mirabilis & MIC & n.m. & n.m. & n.m. \\
\hline & & $\mathrm{DD}$ & $\mathrm{R}$ & $\mathrm{R}$ & $\mathrm{R}$ \\
\hline 17 & Candida albicans & MIC & n.m. & n.m. & n.m. \\
\hline
\end{tabular}

DD - Disc diffusion (zone of inhibition including the diameter of disc $6 \mathrm{~mm}$ ), R - resistant with zone of inhibition 0 - 14 mm, M - moderate susceptible with zone of inhibition 14 - $19 \mathrm{~mm}$ and S - susceptible microorganism with zone of inhibition 19 - $30 \mathrm{~mm}$ ); MIC - minimum inhibitory concentration ( $\mu 1 /$ $\mathrm{ml}) ;$ n.m. - not measured. 
ous tested microbial strains. Essential oil (Juniperi aetheroleum) obtained from the juniper (J. communis) berries was evaluated for the antimicrobial activity against sixteen bacteria, seven yeast-like fungi, three yeasts and four dermatophyte strains. Juniper essential oil showed similar bactericidal activities against Gram-positive and Gram-negative bacterial strains, with MIC values between 8 and $70 \%$ $(\mathrm{V} / \mathrm{V})$, as well as a strong fungicidal activity against yeasts, yeast-like fungi and dermatophytes, with MIC values below $10 \%(\mathrm{~V} / \mathrm{V})$. The strongest fungicidal activity was recorded against Candida spp. (MIC from 0.78 to $2 \%, \mathrm{~V} / \mathrm{V}$ ) and dermatophytes (MIC from 0.39 to $2 \%, \mathrm{~V} / \mathrm{V}$ ). GC/MS analysis of the essential oil showed that predominant constituents in this oil were $\alpha$-pinene (29.17\%), $\beta$-pinene (17.84\%), sabinene $(13.55 \%)$, limonene $(5.52 \%)$ and $\beta$-myrcene $(0.33 \%)$ (Pepelnjak et al., 2005). The essential oil of $J$. communis growing wild in Kosovo, showed moderate to high activities against Staphylococcus aureus, Escherichia coli and Hafnia alvei, while Pseudomonas aeruginosa was resistant to the antimicrobial effects of the oil (Haziri et al., 2013). The leaves essential oils of $J$. communis subsp. hemisphaerica and $J$. oblonga from Iran did not show noticeable activity against Bacillus subtilis, Staphylococcus aureus, Escherichia coli, Pseudomonas aeruginosa and Candida albicans (Asili et al., 2008). Angioni et al. reported similar results concerning the antimicrobial activity of the essential oils from ripe and unripe berries and leaves of Italian $J$. communis against the most of the above mentioned microbial.

\section{Conclusion}

The essential oil (LEO) isolated from tree different leaves samples of wild growing Juniperus communis L. (Cupressaceae), from R. Macedonia was characterized with presence of $\alpha$-pinene $(21.37-28.68 \%)$ and sabinene (2.29-16.27\%), followed by limonene, terpinen-4-ol, $\beta$-elemene, trans $(\mathrm{E})$-caryophyllene, germacrene $\mathrm{D}$ and $\delta$ cadinene. Antimicrobial screening of the LEOs against 16 bacterial isolates of Gram positive and Gram negative bacteria and one strain of Candida albicans, showed the strongest antimicrobial activity towards Staphylococcus aureus and Streptococcus pyogenes (MIC $=125 \mu \mathrm{l} / \mathrm{ml}$ ) and moderate antimicrobial activity against Streptococcus agalactiae, Haemophillus influnzae, Corynebacterium spp. and Campylobacter jejuni (MIC > $500 \mu \mathrm{l} / \mathrm{ml})$. On the other hand, Candida albicans, Staphylococcus epidermidis, Acinetobacter spp., Salmonella enteritidis, Shigella flexneri, Klebsiella pneumonia, Pseudomonas aeruginosa and Proteus mirabilis were completely resistant to the antimicrobial effects of $J$. communis LEO.

\section{References}

Adams, R., 2007. Identification of essential oil components by gas chromatography/mass spectrometry. 4th Ed. Illinois: Allured Publishing Corporation.
Angioni, A., Barra, A., Russo, M.T., Coroneo, V., Dessi, S., Cabras, P., 2003. Chemical composition of the essential oils of Juniperus from ripe and unripe berries and leaves and their antimicrobial activity. J. Agric. Food Chem. 51 (10), 3073-3078.

Asili, J., Emami, S.A., Rahimizadeh, M., Fazly-Bazzaz, B.S., Hassanzadeh, M.K., 2008. Chemical and antimicrobial studies of Juniperus communis subsp. hemisphaerica and Juniperus oblonga essential oils. J. Essent. Oil Bear. P1. 11 (1), 96-105.

Butkienë, R., Nivinskienë, O., Mockutë, D., 2005. $\alpha$-Pinene chemotype of leaf (needle) essential oils of Juniperus communis L. growing wild in Vilnius district. Chemija. 16 (1), 53-60.

Chatzopoulou, P.S., Katsiotis, S.T., 1993. Chemical investigation of the leaf oil of Juniperus communis L. J. Essent. Oil Res. 5 (6), 603-607.

Filipowicz, N., Madanecki, P., Gołębiowski, M., Stepnowski, P., Ochocka, R.J., 2009. HS-SPME/GC analysis reveals the population variability of terpene contents in Juniperus communis needles. Chem. Biodiv. 6 (12), 2290-2301.

Haziri, A., Faiku, F., Mehmeti, A., Govori, S., Abazi, S., Daci, M., Haziri, I., Bytyqi-Damoni A., Mele, L., 2013. Antimicrobial properties of the essential oil of Juniperus communis (L.) growing wild in east part of Kosovo. Am. J. Pharm. Toxicol. 8 (3), 128-133.

Koukos, P.K., Papadopoulou, K.I., 1997. Essential oil of Juniperus communis L. grown in northern Greece: variations of fruit oil yield and composition. J. Essent. Oil Res. 9 (1), 35-39.

Kumar, A., Yadav, L.B.S., Ahmad, J., Dubey, N., Puri, S., 2007. Chemical composition of commercial Juniperus communis L. leaf oil. J. Essent. Oil Bear. P1. 10 (4), 310-313.

Micevski, K., 1998. Flora na R. Makedonija. 1st Ed. Skopje: Makedonska akademija na naukite i umetnostite.

Orav, A., Kailas, T., Müürisepp, M., 2010a. Chemical investigation of the essential oil from berries and needles of common juniper (Juniperus communis L.) growing wild in Estonia. Nat. Prod. Res. 24 (19), 1789-1799b.

Orav, A., Koel, M., Kailas, T., Müürisepp, M., 2010b. Comparative analysis of the composition of essential oils and supercritical carbon dioxide extracts from the berries and needles of Estonian juniper (Juniperus communis L.). Procedia Chem. 2. 161-167.

Ottavioli, J., Gonny, M., Casanova, J., Bighelli, A., 2009. Chemical variability of the needle oil of Juniperus communis ssp. alpina from Corsica. Chem. Biodivers. 6 (12), 21922199.

Pepelnjak, S., Kosalec, I., Kalodzera, Z., Blazevic, N., 2005. Antimicrobial activity of juniper berry essential oil. Acta. Pharm. 55, 417-422.

Raal, A., Kanut, M., Orav, A., 2010. Annual Variation of yield and composition of the essential oil of Common Juniper (Juniperus communis L.) branches from Estonia. Balt. For. 16 (1), 50-56.

Shahmir, F., Ahmadi, L., Mirza, M., Korori, S.A.A., 2003. Secretory elements of needles and berries of Juniperus communis L. ssp. communis and its volatile constituents. Flavour Frag. J. 18 (5), 425-428.

Stassi, V., Verykokidou, E., Loukis, A., Harvala, A., Philianos, S., 1995. Essential Oil of Juniperus oxycedrus L. subsp. macrocarpa (Sm.) Ball. J. Essent. Oil Res. 7 (6), 675-676. 


\title{
Резиме
}

\section{Хемиски состав и антимикробната активност на етерично масло изолирано од листовите на Juniperus communis L. (Cupressaceae) од Република Македонија}

\author{
Флореша Села ${ }^{1}$, Марија Карапанџова ${ }^{1}$, Ѓ оше Стефков ${ }^{1}$, \\ Ивана Цветковиќ ${ }^{1 *}$, Елена Трајковска-Доќиќ ${ }^{2}$, Ана Кафтанџиева ${ }^{2}$, \\ Светлана Кулеванова ${ }^{1}$
}

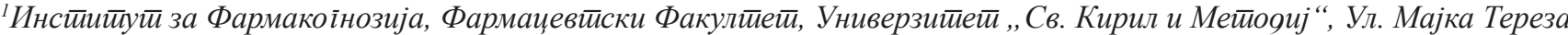
47, 1000 Скойје, Рейублика Макеоонија

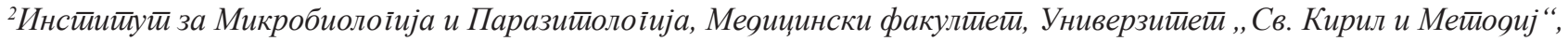
Ул. 50 Дивизија бр. 6, 1000 Скойје, Рейублика Макеоонија
\end{abstract}

Клучни зборови: Juniperus communis, етерично масло од листови, состав на масло, GC/FID/MS анализа, антимикробно дејство

Главна цел на студијата беше испитување на хемискиот состав и антимикробната активност на етеричното масло изолирано од листовите на три различни популации на диво растечки Juniperus communis L. ( Cupressaceae ) од Република Македонија. Приносот на дестилираните етерични масла се движи од 7.3 до $9.0 \mathrm{ml} / \mathrm{kg}$. Co GC/FID/MS анализа беа идентификувани вкупно деведесет компоненти што претставуваат 86.07-93.31 \% од маслото. Најзастапени компоненти во етеричното масло од листовите беа: $\alpha$-пинен ( $21.37-28.68$ \%) и сабинен ( $2.29-16.27$ \%), проследени со помали количества на лимонен, терпинен-4-ол, $\beta$-елемен, Е-кариофилен, гермакрен D и $\delta$-кадинен. Антимикробната активност на маслото беше определена со диск дифузиона и агар дилуциона метода на 16 бактериски изолати на грам позитивни и грам негативни бактерии и еден вид на Candida albicans. Две бактерии, Staphylococcus aureus и Streptococcus pyogenes беа чувствителни на маслото од смрека, со MIC=125 $\mu 1 / \mathrm{ml}$. Етеричното масло од листови покажа умерено антимикробно дејство против Streptococcus agalactiae, Haemophilus influnzae, Corynebacterium spp. и Campylobacter jejuni (MIC> 50 \%). Candida albicans, Staphylococcus epidermidis, Acinetobacter spp., Salmonella enteritidis, Shigella flexneri, Klebsiella pneumonia, Pseudomonas aeruginosa и Proteus mirabilis беа потполно резистентни на маслото изолирано од иглички на J. communis. 
